\title{
Legislative Candidate Selection in the Hungarian and Lithuanian Communist Successor Parties
}

\author{
Tatiana P. Rizova \\ Department of Government, Christopher Newport University \\ 1 University Pl., Newport News, VA 23606, USA \\ Tel: 1-757-594-7971_E-mail: tatiana.rizova@cnu.edu
}

Received: February 21, 2012 Accepted: March 23, $2012 \quad$ Published: June 1, 2012

doi:10.5539/res.v4n2p56

URL: http://dx.doi.org/10.5539/res.v4n2p56

The research is supported by the Open Society Foundation, 400 West 59th Street, New York, NY 10019, U.S.A., Tel: 1-212-548-0600, Fax: 1-212-548-4600.

\begin{abstract}
Communist successor parties have experienced rapid and sudden reversals of their post-transition electoral fortunes. The Hungarian Socialist Party showed an anemic electoral performance in 1990 only to return to power in 1994. The Lithuanian Labor Democratic Party reversed its declining electoral fortunes in 2000 after a fiasco in 1996. A standard explanation in the post-communist democratization literature is that ex-communists do not really win elections so much as center-right incumbent parties lose them. I argue that the Hungarian and Lithuanian communist successor parties did not enjoy happenstance electoral success. The two parties strengthened their electoral performance by decentralizing candidate selection procedures and recruiting mostly those candidates with links to the communist regimes who could convincingly be cast as reformers or liberators.
\end{abstract}

Keywords: Eastern Europe, Democratization, Party organization, Candidate selection, Communist legacies

\section{Introduction}

The irreversible collapse of communism in Eastern and Central Europe ended scores of long-lived dictatorial regimes. The transition from totalitarianism to democracy in the region, however, did not immediately obliterate the political parties that helped install and run these repressive political regimes. It is hardly surprising that ex-communist parties had staying power beyond the moment of democratization. After all, their leaders had spent years accumulating economic resources, which helped these parties' successors distribute highly-coveted patronage in the first few post-communist elections (Note 1). Moreover, one could hardly expect that those who had benefited from the generosity of the communist welfare state would easily forfeit their social benefits and trade them for the untested promises of the newly-hatched democrats.

Macro-political explanations of the staying power of communist successor parties (CSPs) emphasize the effect of pre-communist and communist regime characteristics and legacies on their post-transition electoral fortunes (Note 2) Though these explanations identify important conditions that can make or break a communist successor party, they oftentimes underplay the role of agency. This study focuses on the role of agency in molding the evolutionary path of communist successor parties. The leaders of the more successful ex-communist parties have demonstrated that they can select legislative candidates who can win parliamentary seats in competitive elections. These leaders have also shown that they can craft political messages, platforms, and programs that appeal to significant portions of the electorate.

Undeniably, part of the electoral success of ex-communist parties can be attributed to the failure of their adversaries to offer quick solutions to the economic crises that plagued their countries in the aftermath of democratization. CSPs did reap an electoral bonus due to others' political and managerial incompetence or ill fortune. However, this incompetence cannot fully account for the successful adaptation of some communist successor parties. I argue that CSPs' success in the electoral arena is primarily due to their adaptation to the 
electoral rules that guide inter-party competition in their political systems. Electoral rules, I contend, affect the choices that ex-communist party leaders make in two fundamental ways. First, electoral rules shape the procedures that party leaders adopt for selecting candidates for elected positions. Second, electoral rules affect the profile of the candidates chosen to run under the party label in electoral contests.

In this study, I focus on the effects of mixed electoral systems on communist successor parties' adaptation mechanisms by examining the Hungarian and Lithuanian CSPs. Hungary and Lithuania adopted mixed electoral systems in the post-communist era. Both countries' systems include a candidate and party-centered ballot; individual candidates compete in single-seat districts (SSDs) in the former, whereas candidate slates compete on party lists in the latter. The cases of the Hungarian and Lithuanian communist successor parties offer an opportunity for comparative analysis of the adaptation strategies of successor parties to mixed electoral systems. I present two hypotheses about the optimal adaptation strategy of a communist successor party competing in a mixed electoral system.

Hypothesis 1: Candidate selection is likely to be more decentralized in the candidate-centered tier of mixed electoral systems than in the party-centered tier.

Hypothesis 2: Ex-communist parties are less likely to nominate candidates with links to the communist regime in the candidate-centered tier of mixed electoral systems than in the party-centered tier.

I derive the following predictions about the adaptation strategies of the Hungarian and Lithuanian ex-communists. First, I expect to observe a more decentralized procedure of legislative candidate selection in the candidate-centered tier of the Hungarian and Lithuanian ex-communist parties. Second, I expect to observe a higher proportion of legislative candidates with links to the communist regime on these parties' lists (party-centered tier) than in the single-seat districts (candidate-centered tier).

\section{Electoral Rules and Patterns of Communist Successor Party Adaptation to Democratic Competition}

Electoral systems could be categorized into three groups - candidate-centered, party-centered, and mixed. In candidate-centered systems, voters choose among candidates who compete individually as in plurality and majority runoff systems. The critical characteristic of the candidate-centered system is the higher salience of candidates' reputation relative to party reputation in affecting voters' decisions. In party-centered systems, on the other hand, voters choose among party lists as in closed-list proportional representation. Party reputation is relatively more important than candidate reputation in party-centered systems. In mixed systems both candidate and party reputation carry weight in voters' final decisions about which candidate or party list to support as in preferential ballot proportional representation systems. In these systems voters get to choose their favorites within the party list of their choice.

\subsection{Determinants of candidate selection methods}

There is a growing literature on the determinants of candidate selection methods in the scholarly work on political parties. Some authors have argued that candidate selection is affected by electoral system attributes. (Note 3) Plurality electoral systems in single-seat districts tend to be associated with decentralized candidate selection, whereas proportional representation systems tend to be associated with centralized candidate selection, the argument goes (Note 4). I find it plausible for the following reasons. In plurality elections voters cast a ballot for a candidate, which highlights the importance of the candidate's qualities and personal reputation (as opposed to highlighting the importance of the party's reputation). One could argue that local constituencies, including local party leaders, have better information about a candidate's potential to generate the voter support necessary to win her district. After all, national party leaders have a stake in choosing viable candidates, even if this means that leaders have to relinquish some authority by involving local-level constituencies in the candidate selection process. National party leaders will most likely not abdicate full responsibility of candidate selection to local-level decision makers. They will reserve the right to veto candidates they find unsuitable or likely to break party ranks once they are in office. Local-level decision makers, on the other hand, will have an incentive to perform well in selecting the best and the brightest candidates in candidate-centered competition, if they wish to participate in the nomination process in the future (Note 5 ). The national party offices can always revoke the nomination authority they have granted local-level leaders, if the latter do not deliver results through their choice of candidates. Since local and national level officials engage in repeated interactions, local-level selectors will most likely have the incentive to recruit viable candidates. The most decentralized candidate selection procedure places control over both nominations and vetoes over candidate nominations in the hands of local-level decision makers. The most centralized procedure, on the other hand, concentrates authority over nominations and vetoes in the national party headquarters. 


\subsection{Determinants of candidate profile}

Assuming that most voters cast a moral vote, and that they prefer democracy to authoritarianism, they will reject the candidacies of political aspirants who have a clear link to the authoritarian past (Note 6). Most collaborators with the state security apparatus, who happen to be responsible for abominable human rights violations, are shielded because their names appear only in classified documents (Note 7). Political leaders, on the other hand, were almost always in the public eye. The advantage of competitive elections in post-authoritarian settings is that voters have the chance to cast a vote for candidates who had no ties to the authoritarian regime. Voters will now evaluate candidates based on candidates' personal political record and party affiliation. However, not all candidates with authoritarian links will be doomed. Membership in authoritarian parties, for the most part, indicates political ambition rather than a serious commitment to the authoritarian ideology or involvement in its repressive apparatus. Even though some candidates may have served in higher ranking positions in the authoritarian party hierarchy, voters may still give them a chance to participate in democratic politics.

The weight of authoritarian legacies is not borne equally by all aspirants with ties to an authoritarian regime. Having established a record of dissident or reformist activities inside the party during authoritarianism or democratization, for example, is one possible strategy of 'cleansing' one's reputation. In fact, individuals with a strong dissident record may be in a better position to present themselves as democrats than any newcomer without a political record. Dissident activity inside the ranks of the communist party, one may argue, was probably the only feasible strategy of affecting policies under communism. Thus, it is important to understand the subtle nature of the authoritarian link and its potential consequences for the reputation of a candidate and the party she represents. I expect that, ceteris paribus, candidates with authoritarian links are less likely to be elected than candidates without such links. (Note 8) I expect to observe a lower proportion of candidates with authoritarian links in candidate-centered than in party-centered tiers of mixed systems. Accordingly, successor parties that have to compete under candidate-centered electoral rules will have the incentive to select 'clean' candidates rather than candidates with authoritarian links (Note 9).

\subsection{Testing implications of the effects of electoral systems on successor party adaptation strategies}

I expect that the Hungarian and Lithuanian electoral systems will prompt changes in both candidate selection procedures and candidate profiles. I derive the following implications based on the two hypotheses articulated in the introduction.

Implication 1. Successor parties will likely adopt more decentralized candidate selection procedures in candidate-centered contests than in party-centered races.

Test 1a. I compare the candidate selection procedures of the Hungarian Socialist Party in the candidate and party-centered races.

Test $1 b$. I compare the candidate selection procedures of the Hungarian Socialist Workers' Party in the candidate and party-centered races.

Test 1c. I compare the candidate selection procedures of the Lithuanian Democratic Labor Party in the candidate and party-centered races.

Implication 2. Those successor parties that choose to decentralize selection procedures in candidate-centered races will perform better than those that fail to do so.

Test 2. I compare the selection procedures in candidate-centered races of the Hungarian Socialists and the Hungarian Socialist Workers' Party in the 1990 and 1994 elections and their effect on electoral outcomes.

Implication 3. Successor parties will perform better in those candidate-centered races where they chose to decentralize candidate selection procedures.

Test $3 a$. I compare the selection procedures in candidate-centered races of the Hungarian Socialists in 1990 and 1994 and their effect on the Socialists' electoral performance.

Test $3 b$. I compare the selection procedures in candidate-centered races of the Lithuanian Democratic Labor Party in 1996 and 2000 and their effect on the LDLP's electoral outcomes.

Implication 4. Successor parties will likely select a smaller proportion of candidates with authoritarian links in candidate-centered races than in party-centered contests.

Test 4a. I compare the candidate profiles of the Hungarian Socialist Party in the candidate and party-centered races in 1990 and 1994. 
Test $4 b$. I compare the candidate profiles of the Hungarian Socialist Workers' Party in the candidate and party-centered races.

Test 4c. I compare the candidate profiles of the Lithuanian Democratic Labor Party in the candidate and party-centered races in 1996 and 2000.

Implication 5. Those successor parties that choose to nominate candidates without authoritarian links in candidate-centered races will perform better than those that fail to do so.

Test 5. I compare the candidate profiles in candidate-centered races of the Hungarian Socialists and the Hungarian Socialist Workers' Party in the 1990 and 1994 elections and their effects on electoral performance.

\section{Ex-Communist and Historic Parties in Hungary and Lithuania}

During the democratic transition in Hungary the party that had sustained the communist dictatorship - the Hungarian Socialist Workers' Party (HSWP) - split into two rival successors. The social democratic Hungarian Socialist Party (HSP) has been more successful than the Marxist-inspired Hungarian Socialist Workers' Party (HSWP) in terms of votes and seats won in parliamentary elections (Note 10). The split was provoked by ideological differences between the moderate and conservative leaders in the HSWP. While the former sought to push the party in a social democratic direction, the latter preferred to keep it closer to traditional Marxist teachings. Though ideological differences inside the party were patent prior to the transition, the formal split did not occur until the founding congress of the Hungarian Socialist Party in October 1989 (Note 11). The HSWP, thus, has two formal successors - the Hungarian Socialist Party and the Hungarian Socialist Workers' Party (now Hungarian Communist Workers' Party).

The Lithuanian Democratic Labor Party (LDLP) is the official successor of the Communist Party of Lithuania (CPL). The metamorphosis of the CPL took place at its $20^{\text {th }}$ Congress, in which delegates decided its post-communist fate. The first major decision, initiated by a reformist group within the party, led to the split of the CPL from the Communist Party of the Soviet Union (CPSU), which had sustained it through the communist era. Rival groups within the CPL differed on two main issues - the party's course of development after earning its autonomy from the CPSU and Lithuanian independence. After 60 years of Soviet subordination, Lithuanians were yearning after independence, much like the independence enjoyed by other countries in the region. The reformist CPL faction won both on the party secession and national independence front. The LDLP became the home of those reform communists who had not abandoned the CPL and joined opposition parties. The hard-line party wing was sidelined, and currently exists as an extra-parliamentary party under the name CPL/CPSU; it is reputed for being the party that refused to formally sever its links with the CPSU. The hard-liners severely compromised their chance for electoral success when they decided to support the Soviet putsch against Lithuanian independence (Note 12). The LDLP, however, faced competition from a historic left-wing party - the Lithuanian Social Democratic Party (LSDP) (Note 13). The LSDP, which claimed to be the only rightful heir of the social democratic tradition in Lithuania, was officially re-established in August of 1989. The original LSDP, which the newly fledged party claimed to have succeeded, had been founded in 1896 .

In both countries, there were three party organizations vying for the votes of the left-leaning electorate - the reformist ex-communist wing, the orthodox ex-communist wing, and a resurrected historic party that had been banned under communism. The reformist and orthodox branches of the communist party differed in their vision for the post-communist development of their party organizations and their countries. The reformists sought to build the reputation of advocates of democracy, which was facilitated by their clash with the orthodox supporters of traditional Marxist values. While the reformers fought to rid themselves of the authoritarian legacy and the hard-liners chose to embrace it, the historic parties could credibly argue that they were the victims of communism and had no ties to the communist regime.

\section{Adaptation Strategies of the Hungarian Successor Parties}

\subsection{Electoral rules for parliamentary elections in Hungary}

The dissolution of the Hungarian Socialist Workers' Party led to the creation of two party organizations - the Hungarian Socialist Party and the Hungarian Socialist Workers' Party - which followed distinct developmental paths after transition. While the HSP decentralized candidate selection procedures and has been quite successful in attracting the votes of constituents with social democratic leanings, the HSWP has performed poorly in every democratic election held since transition. The HSWP kept its candidate selection process centralized at all levels (Note 14). Most of the decision making takes place in the national party offices. Though the HSWP party leader did complain that the HSP inherited most of the party resources and attributed the Socialists' electoral success to 
their rosier financial situation, the declining electoral fortunes of the HSWP are not merely the result of its declining financial fortunes (Note 15).

The Hungarian electoral system has been well-described in the literature on electoral institutions in East-Central Europe (Note 16). The post-transition Hungarian electoral system was adopted in 1989. It combines elements of the majority-plurality run-off system in single-seat districts and proportional representation system in multi-seat districts. There are three separate but inter-connected electoral races - a local race in 176 relatively small electoral districts, a regional race in 20 larger electoral districts (with district magnitude ranging between four and twenty-eight), and a national-level race. The national list is merely compensatory. Voters do not cast a separate ballot for the election of candidates who have been placed on the national list; instead the leftover votes from the district and regional races are combined. The third race was introduced as an 'insurance' policy for the high-ranking members of the outgoing ex-communist political elite who feared that the expansion of electoral competition will reduce their chances of re-entering Hungarian politics (Note 17). About a quarter of the legislative seats in the 1990 parliamentary elections were allocated to national list candidates. To establish a regional list the party must have registered candidates under its label in at least one quarter of the single-seat districts within the boundaries of the regional district. To register a national list, the party must have established regional lists in at least seven of the twenty regional electoral districts (Note 18). There is a $5 \%$ electoral threshold, which each party must surpass in order to receive any seats at all. The threshold is double for a two-party coalition. As of 1997, each party participating in an electoral alliance must meet the $5 \%$ threshold individually rather than free-ride on the votes of its coalition partner. Previously, the two coalition partners were eligible to gain parliamentary representation, if they had jointly met the $10 \%$ threshold (Note 19).

Though there are three electoral competitions, Hungarian voters can only cast two ballots - one for an individual candidate and one for a political party of their choice. The two-ballot system allows them to split their ticket; in other words, they can vote for a candidate who is not running on the list of their preferred political party or electoral coalition. The two-round system in the candidate-centered tier allows voters to vote strategically, in the event their favorite candidate does not stand the chance of winning the race in her electoral district. There are also important party registration requirements, which can severely compromise the chances of smaller political formations to compete for parliamentary seats.

\subsection{Candidate selection procedures in the Hungarian Socialist Party and the Hungarian Workers' Party}

How did the Hungarian communist successor parties adapt to the new electoral conditions (Note 20)? While the HSP adopted an optimal strategy of social democratization and selected viable candidates in the 1994 elections, the HSWP walked the Kádárist ideological line and chose lackluster legislative candidates following a highly centralized procedure in both the 1990 and 1994 elections (Note 21). Needless to say, one cannot fully attribute the Socialists' electoral failure in 1990 to the dominance of the party leadership in ideological and organizational decision making (Note 22). Hyper centralization, however, was one of the factors that prevented the party from selecting candidates who were likely to appeal to the leftist voters in the single-seat districts in the 1990 elections. The internal party organization was deficient as it lacked the organizational armature that would enable the party to select better candidates. Racznoted that "candidates for elections were selected by local 'convents' which remained in the hands of the leadership, while on the territorial lists the county party leadership controlled the procedure and on the national list the party centre" (Note 23).

Another perceptible difference between the Socialist candidates and those of the large opposition parties (Alliance of Free Democrats and Hungarian Democratic Forum) was the relatively high proportion of Socialist candidates who had been nominated in all three tiers. Among the successful candidates, nine had been Central Committee members, two had served as heads of secretariat departments, and two had been territorial leaders ( $42 \%$ of all Socialist MPs). Most of them had occupied these leadership positions during the reforms in the late 1980s, and could therefore credibly claim that they had contributed to democratization in Hungary. In spite of that, many voters preferred candidates whose past was unblemished by association with the communist dictatorship (Note 24).

Following the 1990 electoral fiasco, the Hungarian Socialist Party leadership decided to delegate the selection of candidates participating in SSD races to local-level leaders. The local party offices were responsible for the nomination of the most viable political aspirants with local connections (Note 25). The national headquarters reserved the informal right to veto candidate nominations, but in most cases they did honor the endorsements of the local party bosses. The procedure was not fully decentralized (as it would be in the event primary elections were held to choose nominees), as the party headquarters in Budapest retained veto powers over the nominations. (Note 26) Following the 1990 legislative elections in Hungary, "the HSP relied on both a relatively more 
decentralized selection of candidates and centralized vetting mechanisms, which ensured both appealing candidates and cohesive local campaigns. The local party decided the individual constituencies, the county organizations set the county lists, and the central leadership decided the national lists" (Note 27).

Scholars have noted that the HSP leadership was "well endowed with organizational skills and political expertise" (Note 28). Even though the leadership was experienced and judicious enough to select viable candidates, it took organizational transformation and the delegation of the nomination powers to the local level party organization to improve the quality of electoral campaigns. The process of decentralization extended to selecting candidates for regional-level contests too; local party chapters were authorized to select regional list candidates, and were virtually independent from the center (Note 29). The national party list is a "balancing mechanism of party factional interests and a means to solidify alliances between the HSP and union leaders, smaller leftist parties and sympathetic organizations" (Note 30). What was the result of the organizational transformation of the Hungarian Socialist Party? In 1990, only 55 of the 174 HSP candidates proceeded to the runoff round and nearly all of them ranked last among the candidates who had reached the second round. In the 1994 elections, however, 160 of 176 HSP candidates reached the runoff round and 147 won their districts. While most HSP candidates had ranked $3^{\text {rd }}, 4^{\text {th }}, 5^{\text {th }}$, and $6^{\text {th }}$ in the first round of the SSD races in 1990,160 of their 176 candidates ranked $1^{\text {st }}$ and 15 ranked $2^{\text {nd }}$ in the first round of the 1994 SSD races. This sudden electoral reversal ought to be attributed, at least in part, to the better quality of the HSP's candidate pool in 1994.

\subsection{Candidate profile of the legislative candidates of the Hungarian Socialist Party and the Hungarian Workers'} Party in 1990 and 1994

What types of candidates did the Hungarian Socialists attempt to recruit for the single-seat contests, the regional party list races, and the indirectly elected national list? The party sought to emphasize its 'reformed' character through its leadership and legislative candidate recruitment policies and its social democratic program. The leadership also aspired to improve the party image by attracting candidates who were not only good professionals, but were also locally connected (particularly in the plurality tier) and had a record of dissident activities (Note 31). Even prior to de-communization, Hungarian constituents had manifested their interest in calling politicians' attention to local issues. It is reasonable to expect that voters would most likely choose those candidates in the plurality tier who had the highest enthusiasm, interest, and capacity to resolve local issues. In his analysis of the 1985 multi-candidate legislative elections, Rudolf Tökés concludes that "to survive, the local and regional party organizations had no choice but "to go native" (Note 32). The power elites of the small cities and village communities could now embrace local priorities and feel free to disregard the party center's political directives." The 'typical' 1990 candidate in the plurality electoral tier (across all parties) had roots to the district in which he ran, had university education, and had not been a member of the HSWP (across opposition parties).

More often than not, HSP frontrunners in the plurality tier had built the reputation of dissidents inside the communist party itself; they had expressed public criticism of Kádár's policies and refused to conform to the party ideological line or had become distinguished public figures during the Round Table Talks of 1988. It was less common to attract candidates who had fought against the communists' political supremacy outside the party itself. In one case, however, when seeking legislative candidates in the 1990 elections, the Socialists were able to recruit a victim of the communists' repressive policies (Note 33). While this is an exceptional case, it does demonstrate the aspiration of the newly-fledged Socialists to save their party from disgrace. The Hungarian Socialists preferred to place popular politicians on the national list for several reasons. First, by running on a party list these candidates would not risk public humiliation in the event they had lost a district race. Second, their popularity could help boost the vote in district and regional races (positive spillover effect). Third, placing party dignitaries on the national as well as a regional list was a strategy of maximizing their chances of electoral success.

The Hungarian Socialist Workers' Party performed poorly in the 1990 election. It earned 3.68\% of the national vote and was unable to overcome the $4 \%$ threshold. In the very first elections, the HSWP nominated candidates to run in only $56 \%$ of the single-seat races, and lost all of them. None of the HSWP's 99 candidates were among the two frontrunners in these district races (Note 34). In spite of its wretched record, the party leadership did little to change its methods of recruiting legislative talent in the 1994 parliamentary race. The procedure for selecting legislative candidates was uniform in both the candidate-centered and party-centered electoral tier. The national leaders themselves nominated and removed candidates and placed them in electoral districts chosen by the party bosses. The HSWP local party offices did not enjoy the independence that HSP local party officials maintained before the 1994 parliamentary elections. Each nomination was subject to the official stamp of approval of the national headquarters. While the HSP broke with its traditional cadre recruitment policy in which 
decisions were made exclusively by the top echelons of the party hierarchy, the HSWP followed the communist model of selection and approval at the top.

Most of the Socialist Workers' Party candidates in the 1990 and 1994 elections were prominent national-level leaders (Note 35). In itself, placing well-known political contenders in the SSD races was not wrong-headed. Had the HSWP selected less lackluster candidates for these races, it may have come closer to winning some districts; instead, most of its candidates reminded voters of the communist past. Their names were easily recognized by the general electorate, but their links to the authoritarian past prevented them from commanding the attention and attracting the votes of the more moderate left-leaning voters. According to a poll of voters' preferences published in the Hungarian daily Magyar Nemzet in March 1990, the criteria for candidate electability included the following, listed here in order of importance - no previous HSWP membership, middle age, local residency, family man, university graduate, male, white collar, or intellectual and candidate of a large party. The issue of previous association with the communist party figured prominently in voters' minds as an important determinant of their decision to support one candidate or another, one political party or another. While it is clear that most of the HSP legislative candidates in the 1990 parliamentary elections had been HSWP members before transition, the candidate pool of the opposition parties also had some former communists. Certainly, the proportion of the ex-communist members nominated by opposition parties was noticeably smaller. Approximately 7\% of the 1990 legislative candidates of the Hungarian Democratic Forum had been communist party members. More than half of the independent candidates in the plurality tier had been communist party members. The proportion of ex-communist candidates in the smaller opposition parties ranged between $1.1 \%$ and $3.1 \%$ (Note 36). Obviously the options of those aspirants for legislative office who had been HSWP members were somewhat limited. Those who wished to participate in the personalized SSD contests ran either under the label of a communist successor or as independents. With time, the number of independent candidates seeking election has plummeted, and the only avenue for entry of ex-communists into parliament since the 1994 elections is the Socialist Party label.

Table 1 presents the relationship between candidate selection procedures and electoral outcome, controlling for links to the communist dictatorship. It allows us to perform cross-tabulation analysis of 597 candidates of the Hungarian Socialist Party and the Hungarian Socialist Workers' Party who competed in single-seat districts in the 1990 and 1994 elections. The explanatory variable - candidate selection procedure - divides the cases into candidates who were selected through a decentralized procedure (by local-level selectors) and a centralized procedure (by national-level selectors). The control variable - communist links - categorizes the cases based on whether the candidate had occupied a position in the high rungs of the HSWP's organizational hierarchy during communism or not. It excludes the rank-and-file members of the HSWP for two reasons - theoretical and methodological. In theory, it is reasonable to assume that communist links will affect the electability of those candidates who were involved in the upper echelons of the communist regime. Top-level party leaders were generally most visible and most easily associated with the communist legacy; hence, they were most likely to be held accountable for the failures (or credited for the accomplishments of the communist regime) (Note 37).

The data suggest that a decentralized candidate selection procedure improved the electability of both candidates with communist links and those without such links. Among the candidates who were elected through a decentralized procedure, a higher percentage of the winning candidates had communist links $(100 \%$ compared to $84 \%)$. Among the candidates who were elected through a centralized procedure, a higher percentage had no communist links ( $7 \%$ compared to $0 \%$ ) (Note 38 ).

A few details about the reputation of these former first-tier communist party officials are in order. The historical literature on the democratic transition in Hungary and the events that preceded it has documented the positions and the role of many communist party grandees in these political transformations. There is consensus that ImrePozsgay and RezsőNyers, for example, were at the helm of the democratic changes as representatives of the HSWP Politburo. As a matter of fact, Pozsgay had earned the reputation of a critic of communist orthodoxy long before the fateful transition of 1988-89. His doctoral dissertation, which he penned in the late 1960s, presented a solid critique of the communist system and contained seditious notions such as "the separation of the party from the state," the "granting of legitimacy to group interests," the "institutionalization of officials' political accountability, the formal representation of (corporatist) interests at the regional level, and plebiscites to decide certain national interests" (Note 39). As the following excerpt from his dissertation suggests, Pozsgay was particularly concerned about political openness and constituent participation in public affair:

Any kind of democratization must begin with public opinion... We must shape public opinion. [However]... for this task we have created a bureaucratic-manipulative system that, instead of shaping, 
obliterated public opinion... There is more to public opinion than the constant [official] expectation of the public's affirmation of the current political line.

For this and other manifestations of disagreement with communist convention, Pozsgay's dissertation was relegated to the restricted shelves of the Hungarian Academy of Sciences library for twenty years (Note 40). He was one of the masterminds and exponents of the multi-candidate elections held in Hungary in 1985. JánosBerecz was considered an orthodox member of the Politburo as he sought to maintain the party centralized and its central role in Hungarian society in 1988. He had developed the reputation of a "tough and superloyalKádárite" while serving as editor of the major Hungarian daily Népszabadság (Note 41). Since Pozsgay and Nyers had no involvement in the 1956 events and the suppression of the revolutionaries, they weathered the public storm generated by a series of articles in the Népszabadság published under the editorial eye of Berecz. Ironically, the event, which would eventually compromise Berecz's chances of returning to post-communist politics, assumed importance in public forums while he served as the Central Committee Secretary of Information (Note 42).

MiklósNémeth and KárolyGrósz were "middle-of-the-roaders" who sought a balance between the reformist and orthodox party wings (Note 43). Grósz fared poorly in his attempt to enter post-communist politics as the first chairman of HSWP. What ultimately damaged his image beyond repair and committed him to the fringes of Hungarian political life was his inauspicious participation in the government during the 1956 Revolution and his support for the Soviet line at that time (Note 44). The younger generation of party officials, who had ascended to the upper echelons of the hierarchy in the 1980s, was evaluated mostly on its record and involvement in democratization. The older generation of politicians, who had walked the hallways of power in 1956, was evaluated on its record in the events of 1956 and 1988. As Völgyés notes, "for individuals who have based their power on the renunciation of the revolution of 1956 (JánosBerecz, or even Grósz himself), an abrupt change in the evaluation of that revolution, such as the terminology of a "popular uprising" used by ImrePozsgay on January 28, 1989, would bring the personal legitimacy of their position into question" (Note 45). Evaluating the role of these political leaders in monumental historical events is no small task, but at the time of the transition, Pozsgay and Nyers did command the respect of many Hungarians. According to a poll published on August 1, 1989 , Pozsgay enjoyed the approval of $75 \%$ of the respondents (Note 46). Indeed, one of the reasons these two popular politicians were placed on the regional and national lists was to boost support for the party.

While the main focus of this work are the general adaptation strategies of the Hungarian successor parties, the individual survival strategies of the ex-communist party dignitaries also contributed to remaking the party image. Each of the various participants in the transformation of the Hungarian Socialist Workers' Party and the communist regime sought ways to distinguish himself from the rest of the 'pack.' As Tökés notes, "the object was to build a personal political power base for the inevitable next round of contestation for leadership and secure institutional sinecures" (Note 47). In the end, the split between the orthodox ex-communist leaders and the reformed communists worked to the advantage of the HSP reformists who stood out as the more progressive, more dynamic, and more trustworthy of the two groups.

\section{Adaptation Strategies of the Lithuanian Labor Democratic Party and Its Successor}

\subsection{Electoral rules for Parliamentary Elections in Lithuania}

The Lithuanian and Hungarian electoral systems for legislative elections share some features. Lithuanian legislators are elected in two distinct methods. Half of the legislators are elected in single seat districts, while the other half are elected from national party lists. In the 1992 and 1996 elections, candidates competing in single seat districts had to earn an absolute majority of the votes in order to win a parliamentary seat in the first round of the parliamentary elections. The top two candidates had to compete in a runoff election in the event no candidate had gained an absolute majority of the votes in the first round. The electoral law changed in $2000-$ candidates in SSDs would only have to win a plurality of the votes to win a seat, just like candidates in lower-chamber elections in the U.S. The electoral threshold for single party lists participating in the PR tier was $4 \%$ in the 1992 elections, and increased to 5\% in the 1996 elections. The threshold for an electoral coalition is $7 \%$ of the total vote. The 1996 electoral law also introduced important amendments, which raised the thresholds for winning seats in both electoral tiers by introducing turnout requirements. Electoral results in SSDs are only valid if $40 \%$ of the voters turned out at the polls in a given district. At least $25 \%$ of the eligible voters ought to have cast a ballot for a party list to validate the electoral results in the list tier. Candidates are allowed to run in both tiers simultaneously, which could increase a candidate's chances of being elected. Not surprisingly, it is usually party leaders who benefit from this rule. Unlike the Hungarian system, where voters neither rank the candidates on the national list nor cast a ballot directly for the national list, Lithuanian voters are allowed to cast 
positive and negative votes for individual candidates. The final ranking of candidates on the national list is determined through a simple arithmetic of the net positive votes received by candidates and the initial party ranking (Note 48). Thus, the final ranking depends both on the party and the voters. While the law provides for more input on behalf of the voters in deciding the ranking of list candidates, the party influences the ranking in addition to granting ballot access.

\subsection{Candidate selection in the Lithuanian Labor Democratic Party}

Lithuania was the first Baltic country to secede from the Soviet Union in 1990 and almost immediately held its first independent, free and fair legislative elections. The Communist Party of Lithuania (CPL) seceded from the Communist Party of the Soviet Union (CPSU) as soon as the country gained its independence. In 1990 the CPL renamed itself to the Lithuanian Democratic Labor Party and was led into the 1992 parliamentary elections by AlgirdasBrazauskas, who would later become the first democratically elected president of Lithuania. The Lithuanian ex-communists were the only ex-communists in the Baltics to perform well in the founding elections (1992). The Lithuanian ex-communists secured a majority in the Seimas after winning a majority of the seats distributed in both electoral tiers (36 list seats and 37 single seat districts) (Note 49). The Estonian and the Latvian communists have performed very poorly in all elections to date.

I discuss the patterns of political recruitment into the Lithuanian Democratic Labor Party by focusing on the political background of its legislative candidates in the 1996 and 2000 legislative elections. I show that while most candidates of the LDLP had links to the Communist Party of the Soviet Union (CPSU), few of the successful candidates were higher ranking members of the CPSU; most candidates had supported Lithuania's secession and had been active in establishing Lithuanian independence. The fact that the reform wing of the Lithuanian Communist Party had spearheaded independence was an added bonus to the party as its leaders were re-molding its organization and tailoring its ideology. KazimieraPrunskiene, former Lithuanian Prime Minister, noted after the LDLP's electoral victory in 1992.

The LDLP was the first in the former Soviet Union to break away from the control of Moscow, as well as from the reactionary [party establishment] in Lithuania. LDLP members include signers of the Independence Act and co-authors of a wide range of political and economic reforms. This political grouping does, in fact, include a large number of former members of the nomenklatura, yet one cannot ignore the fact that the LDLP ranks include a great many specialists in various fields. Furthermore, there are some LDLP members who have never belonged to the Communist Party (Note 50).

Ishiyama notes some differences between the recruitment practices of the Hungarian Socialist Party and the Lithuanian Democratic Labor Party in the 1992 elections (Note 51). Candidate selection in HSP, he notes, is much more structured than the seemingly haphazard process in the LDLP. "[LDLP] Candidates recruited to run locally tend to be selected on the basis of affiliation with the various patronage networks within the party rather than through input from local party organizations," he claims (Note 52). Krupavičius (1998: 486) claims that the organization of Lithuanian political parties is not "strictly hierarchical." "The structural organization of Lithuanian political parties clearly westernized in the first 5-6 years after independence. Since 1990 all parties based their organization on a territorial principle instead of the territorial-occupational principle of the Soviet era," comments Krupavičius (Note 53). Most of the English-language literature on the organizational re-structuring of the LDLP is quite vague on the issue of legislative candidate selection. What the literature does not fail to mention, however, is the political weight and charisma of the CPL's last General Secretary AlgirdasBrazauskas - and his influence on the organizational choices of the Lithuanian Democratic Labor Party between 1990 and 1996, and the Social Democratic Party of Lithuania after 2001. In the 1992 elections, a year after the CPL had transformed into the LDLP and was on the threshold of an unanticipated electoral victory, the party suffered from a cadre deficit. The LDLP had nominated 71 candidates to compete in the PR tier in 1992, but it won 73 seats based on its list vote. In his analysis of the 1996 election, Krupavičius notes that one of the challenges facing most Lithuanian political parties in 1996 was the need to mobilize the rank-and-file members and local-level party units (Note 54). He also notes that there was definitely a turn to strengthening the local party branches after the LDLP suffered an embarrassing, but anticipated electoral loss in 1996. Still, the LDLP was largely controlled from the top. Clark, Martinaitis and Dilba confirm this observation about the candidate recruitment practices of the LDLP in the 2000 and 2004 elections (Note 55). Candidates in both the plurality and the PR tier of the electoral system were nominated by the national party leadership. The national offices were also responsible for ranking the candidates on the national party list. This consistently hierarchical pattern of recruitment (1992-2004) is different from the fairly decentralized procedures implemented by the Hungarian Socialist Party soon after it lost the founding elections of 1990 . How could we explain the relatively centralized 
recruitment strategies of the LDLP against the backdrop of the decentralized strategies the HSP leadership introduced in the early 1990s?

Between 1990 and 1992, the LDLP was under the strong influence of its charismatic leader AlgirdasBrazauskas. The top party leadership was responsible for most recruitment decisions in the 1990 elections. By 1991, the party had already lost its occupational cells and the leadership was struggling to convert the occupational into territorial cells. Brazauskas resigned from the LDLP top leadership position in 1993 when he assumed the presidency, which produced a power vacuum inside the party organization. It was not until the shock of the electoral loss of 1996 that a dialogue was initiated within the party, which opened up possibilities for strengthening the local party branches and their role in candidate recruitment decisions. The merger of the LDLP and the LSDP in 2000, however, brought about the re-centralization of authority in the hands of the national leadership. The newly-created Social Democratic Party of Lithuania was controlled by a small party elite headed by Brazauskas who became Prime Minister after the 2000 elections. The electoral messages and party program of the LDLP, which appealed to the large Lithuanian social democratic constituency, helped the party secure enough votes in the proportional representation tier. However, the LDLP generally took an electoral beating in single seat districts because it failed to successfully recruit viable candidates. This finding suggests that perhaps centralized candidate recruitment undermined the LDLP's electoral performance in the candidate-centered tier.

\subsection{Candidate profile of the Legislative Candidates of the LDLP}

In this section I discuss the background of LDLP candidates in the 1992 and 1996 elections. Only six CPL dignitaries participated in the 1992 legislative elections. Two of the six ex-communist officials ran on the LDLP label. These were former Politburo member StanislovasGiedraitis and the former Central Committee Head of the Agricultural Committee JuozasŽebrauskas. Neither of the two candidates ran in a single seat district. Giedraitis competed as number 34 on the LDLP national list, and Žebrauskas was number 66 on the list. Since 1992 was an electoral boon for the LDLP, both candidates were elected from the party list. Former Politburo member LionginasSepetys competed as an independent candidate in $58^{\text {th }}$ district, but garnered merely $5.88 \%$ of the district vote, which placed him in $5^{\text {th }}$ position. Justas Paleckis, head of the Ideological Central Committee of the CPL, competed under the label of the Lithuanian Social Democratic Party. He competed in $29^{\text {th }}$ district where he came in second in the first round of the plurality elections, but received only half as many votes as the frontrunner. He was ranked $8^{\text {th }}$ on the LSDP list, but did not win a legislative seat. He is currently representing the Social Democratic Party of Lithuania in the European Parliament. Finally, VaclovasMorkunas, former CPL labor minister competed on the label of the Christian Democratic Party. He ran in $67^{\text {th }}$ district, where he won $19.20 \%$ of the vote, and placed $3^{\text {rd }}$ in the race.

Neither of the two ex-communist dignitaries who participated in the 1996 legislative elections ran on the LDLP label. VytautasAstraukas (former member of the CPL Politburo) and AlgirdasVileikis (former member of the Presidium of the Supreme Soviet) both ran on the label of the Lithuanian Christian Democratic Party (LChDP). Astrauskas was ranked $20^{\text {th }}$ and Vileikis was ranked $5^{\text {th }}$ on the party list. The latter also competed in a district election, in which he secured $9.36 \%$ of the vote ( $5^{\text {th }}$ place). Only one former top official of the CPL ran in the 2000 parliamentary election. VytautasEinoris had served as Chairman of the State Committee for Environmental Protection in the last communist administration. This was his first participation in a national-level election. He won his district with $37.01 \%$ of the vote, and was ranked in $4^{\text {th }}$ position on the list of the Lithuanian Democratic Labor Party. All ex-communist candidates (1992-2000), who had served in the Politburo, the Central Committee, and the cabinet in 1989, were Lithuanian. None of the ethnic Russian top party leaders ventured to re-enter national level politics. If they did, they were probably not the top choice of the Lithuanian political parties.

The authoritarian legacy affected candidate selection and viability in two causal pathways. First, those high-ranking members of the CPL, who could not credibly claim that they had fought for Lithuanian independence or were democrats, simply chose not to return to national politics. They weighed their chances of getting selected by their party and winning in a single seat district and chose to forfeit a national political career. Second, the LDLP leadership itself preferred not to select candidates whose only claim to fame was a leadership position in the Communist Party of Lithuania. In essence, the pre-democratic individual legacy and reputation of most Communist Party officials mattered much less than how they were perceived by the voters during transition. Support for Lithuanian independence and credible dissident activity during transition could make or break the future political career of an ex-communist party official.

\section{Conclusions}

The Hungarian Socialist Party and the Lithuanian Democratic Labor Party improved their electoral performance by adopting successful strategies of adaptation to the electoral rules in their political systems. It took both parties 
an electoral debacle to introduce major changes in candidate selection procedures and candidate profiles. Unlike LDLP bigwigs, HSP dignitaries delegated candidate selection to local party leaders after the 1990 elections. Thus, the Hungarian Socialists were able to draw on local information and knowledge about the viability of legislative candidates in district electoral races. The Lithuanian communist successors performed poorly in the 1996 district races, partly due to the party's overreliance on the vetting coming from the top. The leaders of both parties were capable gatekeepers - they prevented the entry of candidates whose reputation had somehow been tarnished during the communist regime or in the transition period. Certainly, in many cases, the party leaders did not have to play the role of gatekeepers. Political aspirants with clear links to the authoritarian past who could not preen themselves in democratic garb were less likely to affiliate themselves with a political party whose leaders eagerly sought to jettison its communist legacy. The transformational capacity of the Hungarian Socialist Party and its legitimacy as a progressive social democratic party were boosted by the split between the reformist and the orthodox leaders. It was against the backdrop of the political messages of the Hungarian Socialist Workers' Party that the Hungarian Socialists were able to credibly claim that they were more progressive, more democratic, true social democrats. Political aspirants who had built the reputation of dissidents inside the Hungarian Socialist Workers' Party stood to gain from that experience; they were credible democrats, for they had risked their lives instead of being silenced by the party grandees.

Lithuanian ex-communists could present themselves not only as democrats but also as liberators. Those aspirants who had defied Soviet authority either within or outside the ranks of the Communist Party of Lithuania were more likely to be nominated to compete in district contests and be ranked high on the party lists than those who had no dissident experience.

Authoritarian legacies can be overcome. The adaptation of communist successor parties and the candidates they fielded in district contests and regional and national party lists depended not only on their record during communism, but also on their tactics during defining historical junctures (such as the 1956 Hungarian Revolution) and during democratization or independence. Communist party membership, or even leadership, did not presage political suicide when combined with a credible record of dissident activity before and during transition; the absence of such a record, on the other hand, lowered the likelihood of being selected to compete under the label of a communist successor party.

\section{Acknowledgements}

The author would like to thank Iván Berend, Barbara Geddes, Michael Thies, and Daniel Treisman for reading drafts of earlier versions of this work and Bryan Deel for his invaluable research assistance.

\section{References}

Ágh, A. (1995). Partial consolidation of the East-Central European Parties: the case of the Hungarian Socialist Party. Party Politics, 1(4), 491-514.

Benoit, K. (2005). Hungary: Holding Back the Tiers. Politics of Electoral Systems. Cambridge: Cambridge University Press.

Birch, S. et al. (2002). Embodying Democracy: Electoral System Design in Post-Communist Europe. Houndmills, Basingstoke: Palgrave Macmillan.

Clark, T. D., Martinaitis, Z., \& Dilba, R. (2008). Electoral mandate and party cohesion: does it matter in Lithuania. Journal of Communist Studies and Transition Politics, 24(3), 317-337.

Crampton, R. J. (2003). Eastern Europe in the Twentieth Century and After. Routledge: London and New York. Epstein, L. D. (1980). Political Parties in Western Democracies. New Jersey, New Brunswick: Transaction, Inc. Farkas, E., \& Vajda, A. (1995). Candidates for Parliament. In Tóka, G. (Ed.), The 1990 Election to the Hungarian National Assembly (pp. 67-83). Sigma, Berlin.

Geddes, B. (1995). A comparative perspective on the Leninist legacy in Eastern Europe. Comparative Political Studies, 28, 239-74.

Grzymała-Busse, A. (2002). Redeeming the Communist Past: The Regeneration of Communist Parties in East Central Europe. Cambridge: Cambridge University Press.

Harmel, R., \& Janda, K. (1982). Parties and Their Environments: Limits to Reform?. New York: Longman.

Hermens, F. (1972). Democracy or Anarchy?. New York: Johnson Reprint.

Ilonszki, G., \& Kurtán, S. (1993). Hungary. European Journal of Political Research, 24, 445-450. 
Ilonszki, G., \& Edinger, M. (2007). MPs in Post-Communist and Post-Soviet Nations: A parliamentary elite in the making. The Journal of Legislative Studies, 13(1), 142-163.

Ishiyama, J. (2000). Candidate recruitment, party organisation and the Communist Successor Parties: the cases of the MSzP, the KPRF and the LDDP. EUROPE-ASIA Studies, 52(5), 875-896.

Janda, K. (1980). Political Parties: A Cross-National Survey. New York and London: Free Press.

Janusauskiene, D. (2002). In András, B., Ishiyama, J., \& Sharpe, M. E. (Eds.), The Communist Successor Parties of Central and Eastern Europe. London.

Judge, D., \& Ilonszki, G. (1995). Member-constituency linkages in the Hungarian Parliament. Legislative Studies Quarterly, 161-176.

Kitschelt, H., Mansfeldova, Z., Markowski, R., \& Tóka, G. (1999). Post-Communist Party systems: Competition, Representation, and Inter-Party Cooperation. Cambridge: Cambridge University Press.

Körösényi, A. (1999). Government and Politics in Hungary. Budapest: Central European University Press.

Krupavičius, A. (1998). The Post-Communist transition and institutionalization of Lithuania's parties. Political Studies, 46(1), 465-491.

Laffin, M., Shaw, E., \& Taylor, G. (2007). The new sub-national politics of the British Labour Party. Party Politics, 13(1), 88-108.

Law on Elections to the Seimas. (2010). World Law Guide database. [Online] Available: http://www.litlex.lt/Litlex/Eng/Frames/Laws/Documents/25.HTM (September 9, 2010).

Moldován, T. (1990). SzabadanVálasztott. ParlamentiAlmanach. Idegenforgalmi Propaganda Kiadó, Budapest.

Nalepa, M. (2010). Skeletons in the Closet: Transitional Justice in Post-Communist Europe. Cambridge: Cambridge University Press.

Popescu, M., \& Hannavy, M (2001). Project on Political Transformation and the Electoral Process in Post-Communist Europe. [Online] Available: http://www2.essex.ac.uk/elect/electer/lt_er_nl.htm

Pozsgay, I. (1969). Some Questions on the Further Development of Socialist Democracy and Our Political System. dissertation for the degree of Candidate of Sciences in Philosophy. Hungarian Academy of Sciences, (unpublished).

Prunskiene, K. (1993). Lithuania Today: Politics and Economics. Journal of Baltic Studies, 24(3), 316.

Racz, B. (1991). Political Pluralisation in Hungary: the 1990 Elections. Soviet Studies, 43(1), 107-136.

Racz, B. (1993). The Socialist-Left opposition in Hungary. Europe-Asia Studies. 45(4), 647-670.

Racz, B., \& Kukorelli, I. (1995). The 'Second Generation' Post-Communist elections in Hungary in 1994. Europe-Asia Studies, 47(2).

Róna-Tas, A. (1991). The Selected and the Elected: The Making of the New Parliamentary Elite in Hungary. East European Politics and Societies.

Tökés, R. (1996). Hungary's Negotiated Revolution: Economic Reform, Social Change and Political Succession, 1957-1990. Press Syndicate of the University of Cambridge, Cambridge.

Vőlgyés, I. (1989). Leadership drift in Hungary: empirical observations on a normative concept. Studies in Comparative Communism, 22(1), 23-41.

Waller, M. (1995). Adaptation of the former Communist Parties of East-Central Europe: a case of Social-Democratization. Party Politics, 1(4), 473-490.

\section{Notes}

Note 1. Kitschelt et al., 1999

Note 2. Ágh, 1995; Kitschelt et al. 1999; Waller, 1995

Note 3. Epstein, 1980; Hermens, 1972

Note 4. Harmel \& Janda, 1982

Note 5. Grzymała-Busse, 2002: 216

Note 6. A moral vote is based on voters' moral response to candidates' possible complicity with the communist authorities. Voters who support the ancien régime are more likely to vote for a candidate (or party) who had 
links with this regime than those who oppose it. However, support for an authoritarian candidate does not necessarily imply support for the ancien régime.

Note 7. Politicians in some countries responded to pressures to initiate lustration procedures (Poland), whereas leaders in other countries restricted access to classified documents for a limited time (Bulgaria). See Nalepa (2010) for an in-depth discussion of these deliberations and legal arrangements.

Note 8 Some scholars may find the assumption that voters prefer democracy to authoritarianism strong. Some voters do indeed associate authoritarianism with stability, employment, and security and will gladly trade a democratic for authoritarian government in the short run albeit they are aware of its negative long-term consequences.

Note 9. Yet another caveat one ought to consider is the political background of the selectors (those who nominate and approve candidates) themselves. The authoritarian links of the selectors (i.e. party leaders at the local or national level) will probably influence their nomination decisions and affect the probability of selecting candidates with authoritarian links. If voters' decisions are based on moral grounds is correct, however, choosing candidates with authoritarian links is not an equilibrium strategy, for successor parties may risk electoral failure.

Note 10. The second successor has changed its name three times since 1989. It competed in the 1990 elections under the name Hungarian Socialist Workers' Party (HSWP) and was renamed to the Hungarian Workers' Party (HWP) in 1993. It is currently known as the Hungarian Communist Workers' Party to distinguish it from the Workers' Party of Hungary, which was formed in 2005 after a group of hard-liners split from it. I will refer to it as the HSWP throughout the article for the sake of consistency, even though it took different names.

Note 11. Körösényi, 1999: 47

Note 12. Janusauskiene, 2002: 228

Note 13. Historic parties are those political parties that existed in the pre-communist era and were re-established after communist collapse (Geddes, 1995).

Note 14. One possible explanation for the top-down manner in which party affairs are run is the size of the party. Granted, it is much easier for a small party elite to govern a small party than a large one.

Note 15. Let us entertain the following counterfactual - would the party leadership have maintained the party's traditional leftist appeal had it inherited more resources after the party split? In other words, is the lack of transformation due to the lack of resources or the lack of willingness to initiate organizational and programmatic transformation? The Socialist Workers' Party electoral messages consistently reveal that the lack of transformation cannot be attributed to the scarcity of party finance.

Note 16. Benoit, 2005; Birch et al., 2002

Note 17. Benoit, 2005

Note 18. Birch et al., 2002: 63-64

Note 19. The rules of the Hungarian electoral system - electoral thresholds, the inter-linked electoral tiers, and the registration requirements - favor big parties by design. The optimal strategy for any party that wants to win a parliamentary majority and form a government, therefore, will be to stay big by appealing to large swathes of the electorate. Such was the ambitious plan of the Hungarian Socialists who sought to win a large number of seats and aspired to participate in government formation.

Note 20. I focus on these two elections because there was a dramatic shift in the Socialists' electoral performance of the Hungarian Socialists. After an electoral debacle in 1990, the Socialists rebounded and won a majority of the SSDs. The SSD tier is where they had suffered a tremendous setback in 1990. Ironically, the Socialists had insisted on the introduction of a single-seat tier during the debates of the new electoral system (Judge \&Ilonszki 1995: 164). The Socialists were hoping to benefit from the name recognition of their frontrunners in the SSD races.

Note 21. Kádár was the president of the Hungarian Socialist Workers' Party that sustained communism in the country. He serving as the top Hungarian communist leader between 1956 and 1988 and was loyal to Soviet foreign policy. His name tends to be associated with Hungarian communism.

Note 22. The Hungarian Socialist Workers' Party and the Hungarian Social Democratic Party also won a few votes from the voters with social democratic leanings. The three leftist parties, however, did not form electoral coalitions. Their total vote amounted to $26.25 \%$. There were quite a few people who wished to support the Hungarian left, but the vote was fragmented among the three parties. The two smaller leftist parties were unable 
to cross the $4 \%$ threshold and did not win any seats, while 18 of the Socialists' 33 seats came from the national list.

Note 23. Racz 1991: 126

Note 24. Moldován 1990; Racz 1993: 663

Note 25. In a 1992 survey of Hungarian parliamentarians, $42.9 \%$ of the respondents who had been elected in the single-seat tier cited constituency service as their most important job. Only 3.3\% of the MPs in this group identified party service as their most important job. In contrast, $15 \%$ of respondents elected from a party list stated that party service was most important, whereas $8.9 \%$ claimed that constituency service was their top priority. Voters have also supported the claim that the most important task of legislators is to provide constituency service and represent constituency demands in the legislature. It is understandable that one indication of candidate electability in SSDs will be ties to the locality and constituency service. Hence, there is a clear incentive to delegate candidate selection to the sub-national party units that have better information about candidate viability.

Note 26. One should not discount the importance of the pre-democratic experience of the HSP leaders with internal party democratization. The Hungarian communists introduced a law that "increased the importance of locality by enabling individual constituents to nominate candidate and also by allowing votes at constituency meetings to determine party nominations" (Judge \& Ilonszki 1995: 163).

Note 27. Grzymała-Busse 2002: 216

Note 28. Ishiyama 2000: 882

Note 29. Racz \& Kukorelli 1995: 263

Note 30. Ishiyama, 2000: 882

Note 31. Róna-Tas 1991: 372-3

Note 32. Tökés 1996: 266

Note 33. Róna-Tas 1991: 366

Note 34. Benoit, 1999

Note 35. There is a tendency for increased local ties and more emphasis on constituency service among legislators elected in the SSD tier. This is partly the case because Hungarian electoral laws allow cumule des mandates - in other words representatives in the national legislature can also hold posts in local level government. As of 2006 more than $60 \%$ of all legislators also held some local political position (Ilonszki \&Kurtan 2007: 970). This feature is typical of the French system, but the trend in France is just the opposite. There is less emphasis on constituency service there and most legislators in the National Assembly deal with national affairs.

Note 36. Farkas \& Vajda 1995: 80

Note 37. The table underreports the extent of candidates' communist links for the simple reason that such data are not publicly available. It is important, therefore, to recognize the limitations of the data presented in the table and the tentativeness of the conclusions that can be derived from it.

Note 38. It is important to keep in mind that the data present some limitations due to the low variation on the control variable. Most SSD candidates in both the 1990 and the 1994 parliamentary elections in Hungary had not served in the top levels of the Hungarian Socialist Workers' Party.

Note 39. Tökés, 1996: 224

Note 40. Tökés, 1996: 225

Note 41. Tőkés, 1996: 240-241

Note 42. Tökés, 1996

Note 43. Vőlgyés 1989: 33

Note 44. The 1956 Hungarian Revolution was the first expression of outrage against Soviet-imposed communism in East Central Europe. It was quenched with the help of the Soviet army, and led to the assassination and imprisonment of tens of Hungarian dissidents and the exile of hundreds more (Crampton, 2003). The reputation of all major political figures in Hungary would later be evaluated based on their involvement or lack of involvements in the 1956 events. 
Note 45. Völgyés 1989: 34

Note 46. Magyar Nemzet, August 1, 1989: 4

Note 47. Tőkés 1996: 291

Note 48. Article 89 of the "Law on Elections to the Seimas," [Online] Available: http://www.litlex.lt/Litlex/Eng/Frames/Laws/Documents/25.HTM

Note 49. Marina Popescu and Martin Hannavy, "Project on Political Transformation and the Electoral Process in Post-Communist Europe," http://www2.essex.ac.uk/elect/electer/lt_er_nl.htm

Note 50. See Prunskiene (1993). The finding that the Lithuanian ex-communists emphasized their professionalism and expertise in their campaigns is consistent with Grzymała-Busse's observation of the rhetoric of the Hungarian Socialists. They also accentuated the professionalism and managerial expertise of their candidates for elected post. Very few other political parties could make the same claim. It appears that the Lithuanian ex-communists also engaged in heresthetics by trying to introduce a new dimension of competition on which they certainly outperformed their rivals.

Note 51. Ishiyama 2000

Note 52. Ishiyama 2000: 883

Note 53. Krupavičius 1998: 486

Note 54. Krupavičius 2001: 140

Note 55. Clark, Martinaitis and Dilba 2008

Table 1. Relationship between candidate selection procedure and electoral outcome, controlling for links to the communist dictatorship

\begin{tabular}{lcccc}
\hline & \multicolumn{2}{c}{ Communist links } & \multicolumn{2}{c}{ No communist links } \\
\hline \multirow{3}{*}{ Won } & Decentralized & Centralized & Decentralized & Centralized \\
& $100 \%$ & $0 \%$ & $84 \%$ & $7 \%$ \\
Lost & $(2)$ & $(0)$ & $(147)$ & $(28)$ \\
& $0 \%$ & $100 \%$ & $16 \%$ & $93 \%$ \\
& $(0)$ & $(6)$ & $(27)$ & $(387)$ \\
\hline
\end{tabular}

Source: Marina Popescu and Martin Hannavy, "Project on Political Transformation and the Electoral

Process in Post-Communist Europe" Candidate-level data on electoral performance of all candidates who competed in the single-seat races in the 1990 and 1994 parliamentary elections in Hungary. Available at http://www2.essex.ac.uk/elect/database/indexCountry.asp?country=Hungary\&opt=can Last accessed September $4,2010$. 